\title{
Basic Mechanism of Sweating and Its Role in Temperature and Appetite Regulation: An Ayurvedic Perspective
}

\section{Sushil Kumar Dubey ${ }^{1}$, Anam Aftab ${ }^{1}$, Suyash Tripathi², Ramesh Kant Dubey ${ }^{3}$, Shivani Srivastava $^{4}$, Yamini Bhushan Tripathi ${ }^{4 *}$}

1. Department of Kriya Sharir, Institute of Medical Sciences, Banaras Hindu University, Varanasi, India221005

2. Dept of Cardiology, Institute of Medical Sciences, Banaras Hindu University, Varanasi, India-221005

3. Department of Swasthavritta and Yoga, Government Ayurvedic College, Varanasi, India-221005

4. Department of Medicinal Chemistry, Institute of Medical Sciences, Banaras Hindu University, Varanasi, India-221005

\section{*Corresponding author}

yamini@bhu.ac.in

\begin{abstract}
Background: Sweat excretion from eccrine sweat glands, is primarily considered for theromoregulation. It loses body heat by means of it is more active during exercise or hot environmental conditions. In Ayurveda, sweat (Sveda) is defined as the waste product of fat tissue (Meda Dhatu). Besides it is also linked to Pitta Dosha, responsible for all metabolic process in the body. Aim and Objective:Thus it is proposed that sweating regulates temperature but also reduces the metabolism. This may lead to loss of appetite, lesser energy and also compromised digestive potential (Jatharagani). Materials and Methods: This review initially focuses on the basic mechanisms of eccrine sweat secretion and its role in temperature regulation from Ayurveda as well as modern point of view followed by critical discussion of Ayurvedic concepts in the light of modern knowledge. Observations: In Ayurveda, collection, transportation and excretion of Sveda is under the regulation of Pita Dosh, Agni, Samana Vayu and Vyana Vayu through Svedavaha Srotas and Ambuvaha Srotas by Gati \& Gyan. Scope and Limitations: This ayurvedic concept has revealed a clear and detail mechanism of temperature and appetite regulation by stomach, Rashdhatu and Lasika. They are taking an important role before the action of blood and sweating. The clinical trial should be done in future to make this concept completely valid.
\end{abstract}

Key Words: Sweat, Sveda, Pitta, Svedavaha srotasa, thermoregulation, digestion, Agni 


\section{Introduction}

Regulation of body temperature is essential for maintaining the normal physiology and biochemistry for smooth functioning of each system and healthy survival of the human being. Vital biological processes operate at a narrow range of temperature and body has physiological mechanisms for this purpose and sweating is one of them.

The sweat is the secretion of sweat glands situated in the skin. Sweating is controlled by the autonomic nervous system. It helps in temperature regulation by means of evaporative heat loss. Exercise or exposure to a hot environment increases internal as well as skin temperatures, thereby increasing the rate of sweating and also the blood flow in skin.

In Ayurveda, sweat (Sveda) has been considered as the waste product of fat tissue (Meda Dhatu). ${ }^{1}$ Sveda is the seat of Pitta-dosha, which performs all the metabolic and heat regulating functions in the body. As per Ayurvedic (ancient medical science) text Sveda, Rasa, Lasika and Rudhira get collected and transported to the hair follicles through Svedavaha and Ambuvahi Srotas respectively. This occurs correspondingly with the help of Samana Vayu and Vyana Vayu. The Samana Vayu is responsible for the collection of Sveda, Rasa, Lasika to their respective Srotas whereas Vyana Vayu is responsible for charge of the secretion of Sveda and flow of Rudhira. ${ }^{2,3}$

\section{Physiology of sweating}

The eccrine glands in the skin are innervated by cholinergic and adrenergic fibers of the sympathetic nervous system. When the body temperature rises, the sympathetic nervous system stimulates the eccrine sweat glands to secrete water to the skin surface, where it cools the body by evaporation. It happens by dilating blood vessels to give off heat and by sweating. Thus, eccrine sweat is an important mechanism for temperature control. Humans have up to four million sweat glands distributed over the body. Approximately three million of these are eccrine sweat glands. The secretary portion of eccrine glands produces an ultra filtrate that is further processed by cell-lining of the duct portion, where re-absorption of sodium occurs, leading to hypotonic sweat and conserving electrolytes. An acclimatized person can produce up to several liters of sweat per hour and ten liters per day ${ }^{4}$ There are also mixed sweat glands called apocrine glands and they are primarily situated in the axillae and urogenital area. They secrete a viscous 
fluid from puberty onwards and responsible for body odor. Both eccrine and apocrine sweat glands are innervated by postganglionic sympathetic fibers. The major neurotransmitter to control eccrine glands is acetylcholine, whereas for apocrine glands, it is catecholamines.

The thermoregulatory center in the hypothalamus controls body temperature by regulating eccrine sweat output and blood flow to the skin. In Brain, this centre is located in the pre-optic hypothalamic regions and responds to changes in core body temperature, hormones, endogenous pyrogens, physical activity, and emotions. ${ }^{5}$ The sweat glands on the palms and soles appear to be activated primarily by emotional stimuli, while axillary sweating is stimulated by both thermoregulatory changes as well as emotional stimuli. In humans, when the ambient temperature is higher than skin temperature, there is evaporative heat loss secondary to sweat secretion from eccrine glands.

The efferent signals from the pre-optic hypothalamus travel to the inter-medio-lateral cell column of the spinal cord and then through the white ramus communicans to synapse in the sympathetic ganglia. From here the postganglionic non-myelinated C-fibers passes through the gray ramus communicans, combine with peripheral nerves and travel to sweat glands ${ }^{6}$. The sweat glands can also be activated by direct action of acetylcholine (cholinergic nerves) on the muscarinic receptors on sweat glands, and also by initiating the axon reflex.

Normally, the internal heat generation due to intense exercise is one cause of sweating, but sinusoidal dynamic exercise due to work load also affects sweating response. It is independent of raised temperature. ${ }^{7}$ Further, possible role of metabo-receptors has also been reported in modulating sweating responses during exercise. ${ }^{8}$ During post-exercise ischemia, blood pressure is also elevated and may therefore contribute to the elevation in sweating secondary to the loading of baroreceptors. ${ }^{9}$

A study says that oxidation of fat to $\mathrm{CO}_{2}$ is the primary source of weight loss. Thus, lungs can be treated as the excretory organ for fat. It removes the locked carbon in fatty acid as $\mathrm{CO}_{2}$ after its oxidation. Thus, Pranayam of Yoga may be considered as having direct effect on controlling fat metabolism in humans. Similarly kidney, saliva, the skin are also important organs for removal of excretory metabolites made in liver. More than 50 lipid metabolites, predominantly the oxygenated lipids, endocannabinoids, and ceramides /sphingoid have been identified in sweat. ${ }^{10}$ this supports the concept of Ayurveda where, it has already been said that sweat is the waste product of fat tissue (Meda Dhatu $)^{11}$. 


\section{The effect of sweating on body temperature and appetite}

Another fact described in Ayurvedic text is that sweat (Sveda) is the seat of Pitta, which itself gives habitat to Agni (biological fire). In other words it can be defined as the group of enzymes, responsible for metabolism. Thus, it could be hypothesized that excess sweating may lead to loss of Agni resulting depressed metabolic processes. To understand this, one should know the basic doctrines and principle of Ayurveda. The Vata, Pitta and Kapha are the three humors or Doshas which maintain the homeostasis of body for proper execution. In the Ayurvedic literature scholars have opined that all the transformations, occurring in the body, are under the authority of Agni which itself resides in Pitta. ${ }^{12}$ In contemporary words it could be said that the active component of the Pitta, which takes part in biological transformation/ metabolic processes is Agni. Further, Acharya Charaka has mentioned various seats of Pitta in the body such as sweat (Sveda), Rasa, lymph (lasika), blood (Rudhira), stomach and the lower $2^{\text {nd }}$ part of duodenum $(\text { Aamashaya })^{13}$. As per Ayurvedic text Sveda, Rasa, Lasika, Rudhira get collected and transported to the hair follicles through Svedavaha and Ambuvahi Srotas respectively. This happens correspondingly with the help of Samana Vayu and Vyana Vayu. The Samana Vayu is liable to acquisition of Sveda, Rasa, Lasika to their respective Srotas. ${ }^{14}$ Further, the transportation and secretion is under the control of Vyana Vayu because it has been said that Vyana Vayu is the only Vayu which is Tiryakgami i.e can move in all the direction and is responsible for the secretion of Sveda, and Asrka (blood). ${ }^{15}$ Further, Vyana itself means contraction and relaxation. So, the amount of Sveda or intensity of perspiration depends upon the Vyana Vayu because of peripheral contraction and relaxation of the vessels.
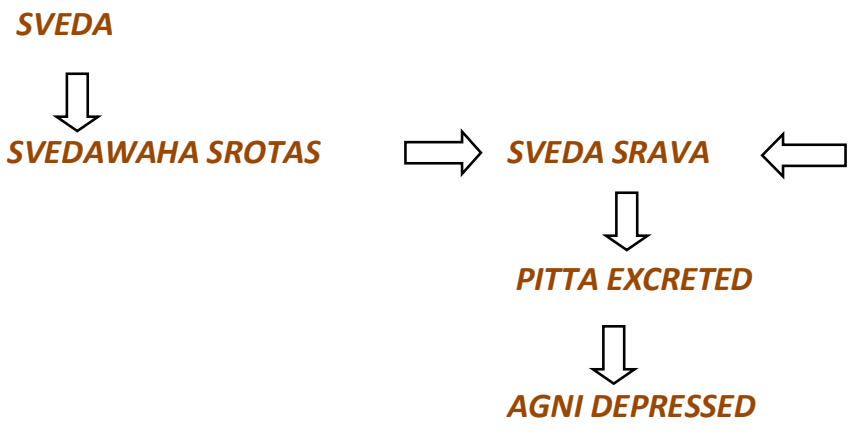

RASA, LASIKA, RUDHIRA

FIGURE 1: MECHASM OF SWEATING AS PER AYURVEDIC CONCEPT. 
The relation between sweating and metabolism including digestion/appetite it could be presumed that once, the Sveda gets excreted out of the body, it also takes Pitta with itself. Due to release of Pitta, its inherent property to keep Agni is also reduced, which can be interpreted by observing the symptoms of reduced agni in the body. These can be seen as reduced unctuousness (Sneha), warmness (Ushna), sharpnesss (Teekshna), liquidity (Drava), acidity (Amla), fluidity (Sara) and being pungent (Katu) ${ }^{16}$ The excess sweating affects the proper sight (Darshan), digestion (Pakti), temperature (Ushma), hunger (Kshut), thirst (Trishna), softness of body (Deha Mardavam), luster (Prabha), contentment of senses (Prasada) and the intellect of an individual (Medha), which are maintained by normal Agni. ${ }^{17}$ On the account of temperature and digestion Ushma guna of Pitta take its authority. Thus after sweating as the Ushma Guna (warmness) of the body gets decreased due to reduction of Pitta, which is directly proportional to the excretion of sweat. This whole process affects the overall physiology, which can be observed in terms of reduction in the body temperature and digestion and which tends to dampen the appetite resulting in compromised Bala or strength of the body. This has been described below through a diagram.

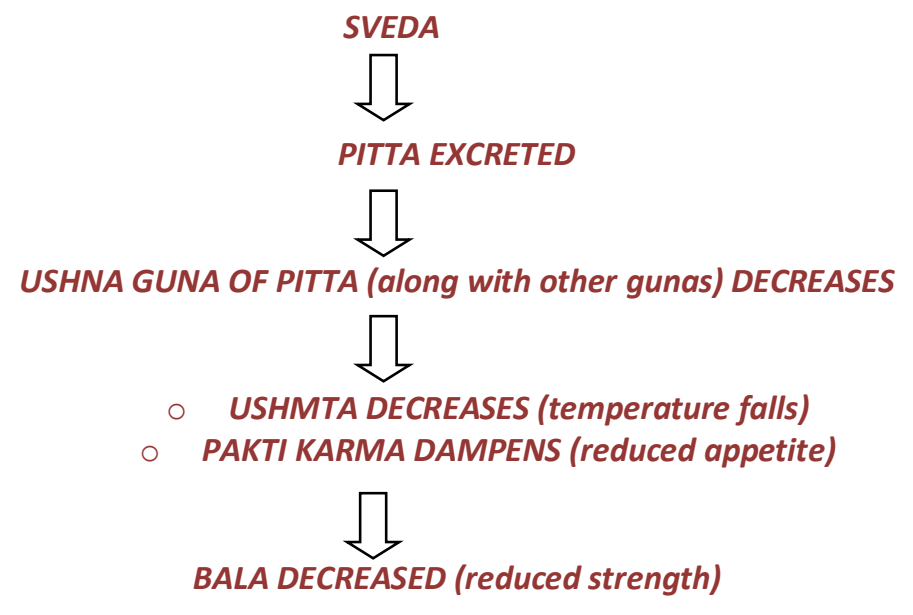

FIGURE2 : REGULATION OF TEMPERATURE.

These physiological changes are also nature dependent, i.e. dependent of seasons. (external environmental factors). As per Ayurveda one year is divided in to 2 parts i.e. Aadana Kaala i.e. from mid January to mid July and Visarga Kaala i.e. from mid July to mid January. In Aadana Kaala the movement of the Sun is in north direction (Uttarayana) and nearest to the earth. It comprises of three seasons from late winter to summer (Shishira, Vasanta and Grishma) and 
called as Uttarayana. ${ }^{18}$ During this period Sun, being strong, draws the essence of earth and wind being strong produce dryness in the environment during, adopting gradual increase from Shishira, Vasanta and Grishma successively. Gradual increase in dryness bring debility ${ }^{19}$ In modern Science, this can be compared with the fixed movement of the earth around the sun to the position, in which the rays of the Sun falls perpendicularly at $30^{\circ}$ meridian of the North Pole on June 21st every year, called as the summer solstice. The northward journey of the Sun from Tropic of Capricorn to Tropic of Cancer happens. ${ }^{20}$

Table 1: With change in position of Sun with respect to earth, there are changes in the 6 seasons and accordingly changes in the physiology as described below.

\begin{tabular}{|c|c|c|c|c|c|c|}
\hline $\begin{array}{c}\text { Shishira } \\
\text { (late } \\
\text { winter) }\end{array}$ & $\begin{array}{c}\text { Magha- } \\
\text { Phalgun }\end{array}$ & $\begin{array}{c}\text { Mid } \\
\text { January- } \\
\text { mid } \\
\text { March }\end{array}$ & $\begin{array}{c}\text { Good } \\
\text { Strength }\end{array}$ & $\begin{array}{c}\text { Least } \\
\text { humid }\end{array}$ & $\begin{array}{c}\text { Least } \\
\text { sweating }\end{array}$ & $\begin{array}{c}\text { Good } \\
\text { appetite }\end{array}$ \\
\hline Vasanta & Chaitra- & Mid & Moderate & Moderate \\
(Spring) & Vaishakha & $\begin{array}{c}\text { March- } \\
\text { mid May }\end{array}$ & Strength & humid & sweating & appetite \\
\hline Grishma & Jyaishtha- & mid May - & Weakness & Highest & Highest & Least \\
(Summer) & Ashadha & mid July & & humid & sweating & appetite \\
\hline
\end{tabular}

In remaining period of the year i.e mid July to mid January known as Visarga Kaala the changes are reversed. The Sun is away from earth, radiated lesser heat to the earth and initiates low environmental temperature (winter season). During this period the Bala (in response to Agni) is on gradual rise. ${ }^{21,22}$

When we create similar situation of perspiration/sweating by exercise, we get similar physiological changes. Just after exercise, there is lesser appetite but it significantly enhances after some time. ${ }^{23}$ Thus in Ayurveda it is recommended not to have heavy food in summers and also just after exercise. ${ }^{24}$

In normal physiological condition, cell prioritizes the use of glucose followed by fatty acids, and finally amino acids, as the energy source to produce ATP. The food crysis induce the synthesis of ketone bodies from fat, which can be used as preferential source of energy, especially to brain. 
Further during intense activity of the nervous system, glycogen is converted to lactic acid in astrocytes and released to be used by neurons. The inactivation of Pyruvate dehydrogenase complex (PDC) in response to both slow-twitch and fast-twitch muscle contraction through upregulated PDK4 can limit the entry of glycolytic products into the mitochondria for oxidation 25,26 .

From biochemical point of view the increase in body-temperature (high thermogenesis) is linked to high rate of ATP production, which is dependent on high rate of utilization of body fuel i.e. glucose and fat. Thus, high perspiration rapidly utilizes energy resulting transient reduced level of ATP in the body. Further, in order to reduce this raised body temperature, there is excess sweating, which also utilizes energy for excretion of sweat, which further reduces the ATP level. This state is similar to transient starvation inducing energy crisis. To compensate this ATP dip, the $1^{\text {st }}$ source of energy production is through $\beta$ oxidation in mitochondria and not glycolysis. It is said that ketosis is the metabolic response to energy crisis to improve the physical endurance by altering fuel competition for oxidative respiration. On the other hand, ketosis also decreases the muscle glycolysis and plasma lactate concentrations by providing an alternative substrate for oxidative phosphorylation. It is known that plasma lactate, produced during heavy exercise, is a cause to raise body temperature and induce sweating). In other words, the ketone bodies are the survival trait conserved in higher organisms to prolong life during an energy deficit or metabolic crisis. It conserves precious glucose/gluconeogenic reserves while simultaneously satisfying the specific fuel demands of the brain ${ }^{27}$. Ketosis may also provide thermodynamic advantages over other carbon substrates by increasing the free energy conserved in ATP $(\triangle \mathrm{GATP})$ by the oxidation of ketones during mitochondrial oxidative phosphorylation ${ }^{28,29}$. Thus oxidation of body fat is the $1^{\text {st }}$ line of fuel during perspiration. This validates the ancient concept of Ayurveda that sweat is the excretory product of fat.

\section{DISCUSSION}

Human body temperature is required to be regulated a narrow range for smooth functioning of physiological processes. When body is exposed to higher temperature either through environmental factors or by increased metabolism, the physiology focused towards reducing the excess heat gets activated. This involves perspiration, a mechanism to cool the body through taking heat for evaporation. This requires activation of eccrine glands for higher rate of 
perspiration. Besides the thermal regulation there are several other factors, integrating with each other, and finally responsible for its activation followed by rapid sweating. Since sweating is both temperature and emotion regulated, so both high body temperature and emotional distress would enhance the perspiration resulting decline in digestive power (Agni). Other scientific reports have also validated this traditional concept of Ayurved ${ }^{30}$. High rate of sweating induces several physiological changes, utilizing high ATP thus creating a transient energy fuel crisis in the cells, resulting ketosis. After cooling the body, the venous blood returns from skin to the body's core and counteracts rising core temperatures. The nerves stimulating the sweat glands, causing perspiration either during physical heat or during emotional stress also controls appetite.

\section{CONCLUSION}

Control of sweating is done by autonomic nervous system. It is regulated by Samana and Vyana $V a y u$, being a subtype of Vata plays important role in carrying Sveda to the hair follicles and regulating the centres present in hypothalamus. Vyana Vayu being Tiryakgami i.e having ability to move in all the directions is responsible for the secretion of Sveda, and Asrka (blood). Primarily sweating is regulated by the integration of internal temperature and external skin temperatures, is paramount for temperature regulation, but there are other non-thermal factors also to regulate sweating, such as exercise, emotions, and fluid status. . Sweat described as Sveda in Ayurveda is one of the seats of Pitta Dosha. Ushma (heat generation/temperature) is one of the functions of Pitta Dosha. When Sveda get excreted out of the body, it also takes out the Pitta contained in it, finally reducing the Agni i.e heat in this context. In this way, sweating helps in loss of heat from the body thus decreasing the body temperature in case of its rise. However, accompanied with this phenomenon, transient increase in fat metabolism and decreased appetite is also observed. In later stage both changes are reversed showing biphasic kinetics of decrease/increase cycle.

Conflict Of Interest: The authors declared no conflict of interest.

\section{REFERENCES}

1. Sharma R.K. \& Dash Bhagawan, Eng. Translation on Charaka Samhita, Chowkhambha Sanskrit Series Office, Varanasi, 2009. Chikitsa Sthan Chapter 15/18. 
2. Sharma R.K. \& Dash Bhagawan, Eng. Translation on Charaka Samhita,Chowkhambha Sanskrit Series Office, Varanasi, 2009.Chikitsa Sthan Chapter 28/8

3. Shastri Ambika Datt, Sushruta Samhita by Maharishi Sushruta with Ayurveda Tattva Sandipika Commentary by, Chaukhambha Sanskrit Sansthan, Varanasi,Eleventh Edition, Vol.2 ,1997. Nidan Sthan ,Chapter 1/17.

4. Groscurth P. Anatomy of sweat glands. Curr Probl Dermatol. 2002;30:1-9.

5. Hölzle E. Pathophysiology of sweating. Curr Probl Dermatol. 2002;30:10-22.

6. Sympathetic innervation of the sweat glands and piloarrector muscles of macaques and human beings.(Uno H J Invest Dermatol. 1977 Jul; 69(1):112-20.s

7. Yamazaki F, Fujii N, Sone R, Ikegami H. Responses of sweating and body temperature to sinusoidal exercise (exercise pressor reflex ) in physically trained men. J Appl Physiol. 1996;80:491-495.), (van Beaumont \& Bullard, Science, 141: 643-646, 1963.

8. Crandall CG, Stephens DP, Johnson JM, Med Sci Sports Exerc. 1998 Apr; 30(4):490-6.

9. Shibasaki M, Kondo N, Crandall CG, (Evidence for metaboreceptor stimulation of sweating in normothermic and heat-stressed humans, J Physiol. 2001 Jul 15; 534(Pt. 2):605-11

10. Karan Agrawal, Lauren A. Hassoun, Negar Foolad, Theresa L. Pedersen, Raja K. Sivamani, andJohn W. Newman' Sweat lipid mediator profiling: a noninvasive approach for cutaneous research J Lipid Res. 2017 Jan; 58(1): 188-195

11. Sharma R.K. \& Dash Bhagawan, Eng. Translation on Charaka Samhita, Chowkhambha Sanskrit Series Office, Varanasi, 2009. Chikitsa Sthan Chapter 15/18.

12. Sharma R.K. \& Dash Bhagawan, Eng. Translation on Charaka Samhita, Chowkhambha Sanskrit Series Office, Varanasi, 2009.Sutra Sthan Chapter 12/11.

13. Sharma R.K. \& Dash Bhagawan, Eng. Translation on Charaka Samhita, Chowkhambha Sanskrit Series Office, Varanasi, 2009.Sutra Sthan Chapter 20/8.

14. Sharma R.K. \& Dash Bhagawan, Eng. Translation on Charaka Samhita, Chowkhambha Sanskrit Series Office, Varanasi, 2009.Chikitsa Sthan Chapter 28/8.

15. Shastri Ambika Datt, Sushruta Samhita by Maharishi Sushruta with Ayurveda Tattva Sandipika Commentary by, Chaukhambha Sanskrit Sansthan,Varanasi,Eleventh Edition, Vol.2, 1997. Nidan Sthan ,Chapter 1/17. 
16. Sharma R.K. \& Dash Bhagawan, Eng. Translation on Charaka Samhita, Chowkhambha Sanskrit Series Office, Varanasi, 2009.Sutra Sthan Chapter 1/60.

17. Sharma R.K. \& Dash Bhagawan, Eng. Translation on Charaka Samhita, Chowkhambha Sanskrit Series Office, Varanasi, 2009.Sutra Sthan Chapter 18/50.

18. Sharma R.K. \& Dash Bhagawan, Eng. Translation on Charaka Samhita, Chowkhambha Sanskrit Series Office, Varanasi, 2009.Sutra Sthan Chapter 6/4.

19. Sharma R.K. \& Dash Bhagawan, Eng. Translation on Charaka Samhita, Chowkhambha Sanskrit Series Office, Varanasi, 2009.Sutra Sthan Chapter 6/6

20. Jayesh Thakkar, S. Chaudhari, and Prasanta K. Sarkar Ritucharya: Answer to the lifestyle disorders, Ayu. 2011 Oct-Dec; 32(4): 466-471

21. Sharma R.K. \& Dash Bhagawan, Eng. Translation on Charaka Samhita, Chowkhambha Sanskrit Series Office, Varanasi, 2009.Sutra Sthan Chapter 6/7.

22. Sharma R.K. \& Dash Bhagawan, Eng. Translation on Charaka Samhita,Chowkhambha Sanskrit Series Office, Varanasi, 2009.Sutra Sthan Chapter 6/8.

23.Serife Vatansever-Ozen, Gul Tiryaki-Sonmez, Guler Bugdayci, and Guclu Ozen The Effects of Exercise on Food Intake and Hunger: Relationship with Acylated Ghrelin and Leptin J Sports Sci Med. 2011 Jun; 10(2): 283-291

24. Sharma R.K. \& Dash Bhagawan, Eng. Translation on Charaka Samhita, Chowkhambha Sanskrit Series Office, Varanasi, 2009.Sutra Sthan Chapter 6/29.

25. Shuai Zhang, Matthew W Hulver, Ryan P McMillan Mark A Cline, and Elizabeth R Gilbert, The pivotal role of pyruvate dehydrogenase kinases in metabolic flexibility, Nutr Metab (Lond). 2014; 11: 10.

26. Herbst EA, Dunford EC, Harris RA, Vandenboom R, Leblanc PJ, Roy BD, Jeoung NH, Peters SJ, Role of pyruvate dehydrogenase kinase 4 in regulating PDH activation during acute muscle contraction., Appl Physiol Nutr Metab. 2012 Feb; 37(1):48-52.

27. Pete J.Cox, Nutritional Ketosis Alters Fuel Preference and Thereby Endurance Performance in Athletes, Cell metabolism 2016, 24,(2), 256-268.

28. A.M. Robinson, D.H. WilliamsonPhysiological roles of ketone bodies as substrates and signals in mammalian tissues, Physiol. Rev., 60 (1980), pp. 143-187 
29.K. Sato, Y. Kashiwaya, C.A. Keon, N.Tsuchiya, M.T. King, G.K. Radda, B.Chance, K. Clark e, R.L. VeechInsulin, ketone bodies, and mitochondrial energy transduction FASEB J., 9 (1995), pp. 651-658

30. Why a sweaty workout dampens appetite https://www.nature.com/articles/d41586-018-04959-8 24 April 2018 